\title{
A Need for Technological Intervention: Children as Rag Pickers in Waste Management of Hyderabad City
}

\author{
Jarupula Saikumar
}

\begin{abstract}
Child labour is a universal problem and it not only hampers the growth and development of the children but also the progress of the nation. Though different nations have come up with various policies and regulations to tackle the problem of child labour, it is still rampant and in India the progress toward the elimination of the child labour is at snail place. In India only after 1971 "International Year of Child" the problems and issues of the children started giving attention on various platforms of the society. The work has been carried out with 250 sample size of the children who are involved with the waste management at various dump yards of Hyderabad city of Telangana state of India. Though government has come up with various policies and regulations to curb the problem of child labour, in reality, the situation is otherwise and the children are visible everywhere in collecting the rag and waste.
\end{abstract}

Keywords: Child labour, Rag- Picking, Waste Management, Hyderabad.

\section{INTRODUCTION}

Today's children only tomorrow's nation. Children play a vital role in the development of the nation and a nation which fails to see the progress of its children is doomed to perish. The latest report by the International Labour Organization (ILO) on child labour reveals the shocking facts about the children in the labour sector. According to the ILO estimates approximately there are 218 million children are employed in various job sectors and among them, 152 million children are found to be the victims of the child labour which not only hampers the growth and development of the children but also the standstills children from being becoming the productive members of the society.

The report by ILO also highlights that around 75 million children aged between 15-24 years are unemployed and those children who are employed working in various sectors which fails to offer them a decent income, social security and premise working conditions. The report by ILO also highlights that achieving one of the primary sustainable goals i.e. providing the decent working condition for all will not be possible without eliminating the child labour. The report also points out that 48 percent of the children aged between 5-11 years are involved with the child labour, 28

\footnotetext{
Revised Manuscript Received on September 25, 2019

Dr Jarupula Saikumar, Ph.D in CSSEIP, University of Hyderabad. Email: saikumarjarupula2001@gmail.com
}

percent of the children between 12 - 14 years of age category and 24 percent of the children of $15-17$ years involves in the child labour.

In terms of the concentration of the child labour across various sectors, agriculture is the largest sector where 71 percentages of the children out of the 152 million child labour are involved with the agricultural sector which comprises the forestry, aquaculture, livestock, fishery and herding etc... After the agriculture sector more number of child labour involved in the service sector i.e. 17 percentage and it is followed by the industrial sector which also comprises the mining.

In terms of the regional prevalence of the child labour the African region is having the highest number of child labour with 19.2 percent of the children involved with the labour sector and it is followed by the Asia - Pacific region where 7.4 percentages of the child labours are involved with child labour activities. These two regions are followed by various other regions like Americas with 5.3 percent, Europe and Central Asia with 4.1 percent and Arab nations with 2.9 percentage of child labour.

The report also emphasizes that in African region one in every five children working as child labour and in Asia-Pacific region the prevalence of the child labour is low compared to that of Africa region where one in every fourteen children employed as child labour. Similarly, in Europe and Central Asia one every twenty - five children engaged in the child labour activity. The prevalence of child labour in Arab nations is least compared to other regions where one in every thirty-five children employed as child labour. The report also stresses on the fact that the prevalence of the boy child labour is more compared to that of girl child labour. But this may be due to the fact that the work by the girl child labour goes un-noticed most of the time, particularly the domestic chores by the girl child labour.

\section{Child labour In India}

In India it was only after 1971 "International Year of Child" the problems and issues of the children started getting attention on various platforms of the society. According to the Child Labour (Prohibition and Regulation) Act 1986, amended in 2016, a child is someone who is below fourteen years of age. The Act prohibits the children (below 14 years) from entering into any form of work including domestic help; it is a cognizable offence to employ the children in any work. Further, the Act prohibits adolescents i.e. children between 14-18 years from hazardous work.

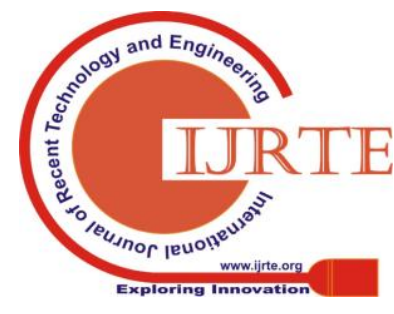


India with its policies and legislations bought down the number of child labour compared to its previous statistics. Though the number of child labour has reduced drastically, the presence of these children visible everywhere. In India, due to poverty, illiteracy, unemployment and lack of education, the children are forced into child labour activities in their early years of life. The latest statistics on the child labour in India reveals that there approximately 10.1 million active child labours are on the ground and many more in un-noticed sectors. UNICEF in its findings reveals that India with the large population has the highest number of labours less than fourteen years of age with agriculture as the largest sector where the most number of children as child labours concentrated.

The recent analysis of by CRY (Child Rights and You) reveals that there are about 15 million of children in the workforce in rural areas as cultivators or in household industries and in urban sectors as servants and construction workers. States like Bihar, Uttar Pradesh, Madhya Pradesh, Rajasthan and Maharashtra contributing the highest child labour in the country. According to the same report by CRY, Uttar Pradesh had 13 Percentage increase in child labour and Delhi, the capital city of India has over one million children employed in labour activities.

According to MINT (The Business News Paper), there are staggering statistical numbers about the child labour in India, though there are many legislations and laws placed in the constitution to tackle the issue of child labour in the country the result for the same is very poor and heartening. According to MINT, one in every eleven kids in India is working. Though child labour is reducing in the country, It is falling at an abysmal rate of 2.2 percent per year since form $2001-2011$. The business daily reveals that 80 percent of the child labours in India are in rural areas and three out of four children are working in the agrarian sector. In India, states like Bihar, Madhya Pradesh, Uttar Pradesh and Maharashtra the concentration of child labour is more, and these states have more than 5.5 million working children who are half of the total working children in the country. The adolescent's ages between 15 to 17 years form 62.8 percentage of total child labour in the country and these children employed in hazardous work. The study reveals that 56 percent of the adolescent's children who are employed are no longer into studies and more boy children, i.e. 38.7 million compared to girl children 8.8 million are employed in unsafe work.

In a study jointly conducted by V.V Giri Labour Institute and UNESCO finds that the incidence of child labour is high in India among the Scheduled Tribe community. Increased economic distress among the rural ST families of the country drives their families to give up their children education and join the work that mostly pays them very less and involves hard work. After STs, the incidence of child labours is more among the Scheduled Castes (SCs). According to the 2011 census $(3.9 \%)$, the incidence of child labour is more among the SCs even though there is declining compared to 2001 $(5.3 \%)$.

The news report published by "The Hindu" reveals that the newly formed Telangana State is on par with other Andhra Pradesh regarding the violence and sexual abuse of the children. The report stresses on the fact that the incidence of child labour is high in Telangana sate especially in the city of
Hyderabad. The child labour in Hyderabad is rampant because of the racket or mafia who brings the children from neighboring states like Orissa, Bihar and other states for small works and minimal wages. Besides this, the report also highlights the pathetic social and living conditions of these children. The study by the Hindu on the high incidence of child abuse Hyderabad city reveals that Hyderabad has the highest concentration of urban child labour in India with 67336 children employed and engaged with various forms of work.

\section{Children as Rag Pickers}

The word 'Rag Picker' refers to the people who collect the rag and other recyclable items and materials. Rag picking involves collecting, sorting and selling of various materials that can be found at dumping grounds, dustbins, community areas and corners of the street or in residential areas etc. The person who involves the collection of the rag and other materials earns money by selling it to a middleman who purchases it and sells it to the third party for higher rates. Rag Picking is an activity mostly dominated by the children and women who don't have any other skill other than collecting and sorting of various materials. Rag picking by the children is a hazardous form of child labour undertaken by the children from low socio-economic sections of the society for supplementing the family income and to survive themselves in society.

The children involved with the rag-picking works hot and humid conditions with the unsafe surrounding which will have adverse negative impacts on the health of the children. The children involved with this activity are mostly abandoned, single parent or from the parentless background. The children get attracted to this job as this job doesn't demand any specific skill and get paid instantly. However, Rag picking is a seasonal activity where summer and winter seasons are being productive and rainy seasons bring a difficulty to their job as the materials get wet and don't have any demand in the market.

Child rag pickers often become the victims of the police and society where the people in the society always have a negative thought about the children involved with the rag-picking activity and likewise children become an easy target for police personnel. There are many studies pertaining to child labour in general and child labour in various sectors in particular but very few studies have done on child labour in the rag-picking sector. Though the state government has come up with various policies and legislation to curb the problem of child labour in the state but the implementation of it has failed to produce the fruitful results. Hence, the current work on children in rag-picking has been carried out in the Hyderabad city of Telangana state of India.

\section{FINDINGS OF THE STUDY}

Due to rapid urbanization, waste management has become a challenge for many nations. In India, due to lack of waste management facilities, the maximum proportions of recyclable items end up in dumping grounds. 
According to the latest reports by ASSOCHAM India is likely to generate an average of 15 lakh Metric Tonnes (MT) E-waste per annum. Among the cities that generating the highest e-waste India, Mumbai tops the list with $96000 \mathrm{MT}$ followed by Delhi-NCR (67000MT), Bangalore (57000MT), Chennai (47000MT), Kolkata (35000MT) and Ahmadabad (26000MT), Hyderabad (25000MT). The report by ASSOCHAM highlights that over 4.5 lakh child labour has been employed in the informal E-Waste management centres without any proper protection and safety measures. All this leads to children exposing to harmful chemicals and radiations.

The article titled "India's challenge in Waste Management" by Down to Earth Magazine, India with 7935 towns and cities and with 377 million urban population producing 62 million tones of municipal waste annually. The experts of waste management believe that India is following the outdated and flawed system of techniques in managing all the waste that comes from various sources. The study also highlights that the number of people in waste management not sufficient enough for the amount of waste produced in the country.

The metropolitan city Hyderabad is producing an average of 5000 MT of garbage every day. Due to its rapid growth in information technology (IT) sector and various available business opportunities the city is attracting a huge population from various states and countries which also involves the people with various social backgrounds. Due to a high number of population immigrants, the amount of waste also raise and then managing the same is a challenge to the municipal authorities. Hence, the current study concentrated on how the shortage of technology and manpower led the children involved in this occupation.

The Greater Hyderabad Municipal Corporation (GHMC) is the official authority for the collection and management of the waste that generating from various sources of Hyderabad city. The GHMC has supplied "Swatch Autos" for the collection of the garbage from residential areas of the city. Under each one of these swatch autos, approximately 800 houses were allotted for the collection of the waste and other materials. The people who are depended on these autos were not given any regular wages and they have to depend on the income that comes from these 800 houses which hardly vary between 50 - 100 rupees per month. Hence, in order to avoid the extra expenses on other people the parents and owners encouraging their own children and other destitute children to take up the activity. As a result of it, many children are dropping out of the school in the name of garbage collection and helping their parents.

Though the GHMC has issued ID cards to people to enter into the garbage centres and to avoid child rag pickers from collecting the rag from dumping grounds but in reality, the security guards who are placed at various centres entertaining the children to collect the rag by paying some commission to them. There were no survey lines at the garbage centres to stop the children from entering into the dumping yards run by the government and other private people.

The study has been conducted on 250 children who are engaged with the rag-picking activity in Hyderabad city. The findings of the study reveal that the number of boy children than girl children are involved with this activity and many of them from socially marginalized sections of the society. 94 percent of the children engaged in this activity are migrated from different parts of India and many of them belong to a single parent and parentless.

Out of the total 250 sample size of the study, more than fifty percent of the children have never attended any school and very few have completed their primary schooling and left their education in order to continue with the rag-picking activity. Absent of adult earning member of the family, illiteracy, ill-health and unemployment of the breadwinner of the family are some of the primary reasons for the children to take up this rag picking activity in early years of their life.

The study finds that rag pickers in general and children in rag-picking do not take any precautionary measures while collecting and sorting of materials at the dumping grounds as well as at any other places they involve. Most of the children in this sector work more than eight hours per day with heavy loads on the back of their shoulders. Glass cuts, dog bites, insect bites, iron cuts on the body of the children are a common thing to find in every child in the study.

In the words of Saidulu - I belong to the Scheduled Community from Medak district of Telangana state of India. I have one wife and two boy children. We are all engaged with this activity since from two years and we have a swatch auto for the collection of the waste from various apartments located in Chandanagar and Lingampalli of Hyderabad city. We all start our work at 6 am in the morning and collect the garbage from 500 flats in 12-15 trips. We divide our work and sometimes my children only take care everything. I know that sending them for work at this age comes under punishable offence but we are helpless and we cannot afford for outside entry to the work. We collect 50 rupees from each flat. Government has given us the gloves only once so far to wear them while collecting and segregating the garbage but now those gloves are torn and we cannot afford to buy them with these little earnings. At garbage centers, we collect and segregate things to sell it to the third man for which we have to bribe the security guard who is placed at the garbage centre. My both sons who are of 14 and 12 years of age often fall into sick but without their help we cannot run house. The GHMC officials never care about our problems and in return they demand money from us to enter into the dumping yards. Last year, we have got the gloves from the officials of the GHMC but it didn't last long and after that we use to collect and segregate the waste with bare hands and at least one injury in a day is a common scenario of our lives.

\section{Conclusion}

A holistic approach is required to deal with the problem of child labour in waste management. There is no official data on the number of child labour engaged in waste management activity. The government should come up with appropriate statistics to deal with the problem of child labour and should provide vocational training to children and their family members in waste management. The dumping grounds should properly utilize by categorizing the type of waste and for the same the Japan system of waste management should be taken as reference. 
Though the state has come up with various amendments and legislation to curb the problem of child labour in various sectors but effective implementation of it should be a monitor with efficient technology.

Identification of child labours, rehabilitation of the child labour is the biggest challenge. Hence, the government should come up with wage generated technologies in waste management, hence, the children along with their parents should adequately trained and placed in the waste management centres.

In the development of the country, the role of the corporate centres is very immense. But the poor are becoming poorer in the process of making the rich richer. The children are becoming the major victims in the process of these developments when they belong to low-income sections. There is an urgent need for making these people socially responsible through proper awareness channels. The government through proper policies should make these corporate people involved in the process of development of these children as healthy individuals.

\section{REFERENCES}

1. Global estimates of child labour (2012 - 2016) by ILO, Geneva, 2017

2. State of the child workers in India by UNESCO and V V Giri labour Institute

3. Old city turns child labour hub (2017) by Ramana N.V

4. India's challenge in Waste Management by Down to Earth, 2019

5. Solid Waste Management in India

6. Over 4.5 lakh child labourers engaged in various e-waste activities in India. ASSOCHAM study, TOI (22 April, 2014).

7. "Problems of working children" by B.Kumar. A.P.H Publishing corporation, New Delhi.

\section{AUTHORS PROFILE}

Dr. Jarupula Saikumar has done his MA, M.Phil and Ph.D from University of Hyderabad. His areas of interests are child labour, Waste Management, Gerontology and Education.

Email:saikumarjarupula2001@gmail.com 